\title{
EL ARQUITECTO JUAN ESPAÑOL
}

Cuando los católicos checos pidieron al general de los jesuitas mandar miembros de la Compañía a Bohemia, lo hicieron directamente a San Ignacio ${ }^{~}$. Así, después de haber encomendado el general a Pedro Canisio (Canissius) ${ }^{2}$ el reconocimiento del terreno, y tras la aprobación del intento por este último, el día 18 de abril de 1556 llegaron a Praga los primeros jesuitas, radicándose en el ex convento dominico de San Clemente de la ciudad Vieja de Praga, al lado del Puente Carlos.

Algo similar ocurrió diez años después en la ciudad de Olomouc, entonces la capital de Moravia y hasta ahora sede del primer obispo de Moravia. El intento del obispo Vilém Prusinovský de Víckov (1565-1572), educado por los jesuitas en Viena y en Roma, de traer a los miembros de la Compañía a la Ciudad de Olomouc, tuvo que ser aprobado por el general de entonces, San Francisco de Borja, a quien le construirían más tarde, después de la canonización, una magnífica estatua en el Puente Carlos, y decenas de esculturas por todo el país ${ }^{3}$ y cuyo hijo, embajador de España en Praga, Juan de Borja, publicó en Praga su libro de Emblémas morales ${ }^{4}$.

El general Francisco de Borja mandó a Olomouc otro español, nada menos que a Jerónimo Nadal, biógrafo de San Ignacio, y asimismo autor de un libro de emblemas, quien llegó a la capital de Moravia en agosto de 1566. Esta visita decidió la existencia de la Universidad de Olomouc ${ }^{5}$. Nadal incluso expresó en aquella oportunidad su esperanza de que con el tiempo se constituyese en la ciudad morava un gran colegio de estudio general. La actual existencia, aunque restringida en la época comunista, de la Universidad, da crédito a su decisión y la gran visión de entonces.

Ya un mes después, en la mitad de septiembre de 1556 llegaron a Olomouc cinco jesuitas y el primer rector, naturalmente español: Hurtado Pérez, quien desempeñó su función hasta el año $1580^{6}$.

Aunque el general Borja rechazó firmar el acuerdo por falta de recursos económicos, ya el año de 1569 los jesuitas mudaron al convento minorita, que les fue ofrecido (en el lugar de la actual iglesia de la Virgen de las Nieves). Hurtado Pérez vino a Olomouc procedente de Trnava 7 , donde también desempeñó de rector. Antes había sido vicerrector del Colegio de Praga, hasta 1560. También en Olomouc se mostró como hábil diplomático, quien imponía de vía directa e indirecta, los intereses de los jesuitas, destacándose por su energía, tenacidad y energía, hasta soberbia ${ }^{8}$. Hurtado Pérez se hizo cargo de la iniciativa y de la empresa constructora de los nuevos edificios de la Universidad, hoy lamentablemente desaparecidos.

\footnotetext{
1 Jiří Kettner, Dějiny pražské aracidiecéze y datech (Historia de la archidiócesis de Praga en fechas). Praha, 1993, pág. 79.

2 Su catecismo Summa doctrinae christianae se utilizaba hasta el siglo xix.

3 Véase P. Stěpánek, «La escultura barroca en Bohemia», Goya, 1969, núm. 92, págs. 104-108. Borja dedicó una copia de la pintura de Santa María de Nieves en Roma, obra de Ignacio Azevedo a la iglesia de la Asunción de la Virgen. Véase J. Bílek, Brněnské kostely (Las iglesias de Brno). Brno, 1985, pág. 49.

4 Juan de Borja, Emblemas Morales. Praga 1581, otras reediciones Bruselas, 1680 y Madrid, 1981.

5 V. Nešpor, Déjiny olomoucké univerzity (Historia de la Universidad de Olomouc). Olomouc, 1947, pág. 16, con referencia a Bohumír Navrátil, Jesuité olomoučti za protireformace, I. (Los jesuítas en Olomouc durante la contrarreforma). Brno, 1916, pág. 12; ya en 1555, el obispo Markus Khuen reservó para la compañia el convento minorita, a la sazón vacío, para la Compañia. A propósito de sus emblemas, véase Campa P. F.: «Jerónimo Nadals Emblems and St. Ignatius' Spiritual Exercises». Cit. según Lubomír Konečný, "Bohuslav Balbín a Emblematika", in: Bohuslav Balbín a kultura jeho doby v Čechách. (Bohuslav Balbín y la cultura de su época en Bohemia). Acta de la conferencia en el Museo Nacional de Literatura, Praga, 1992, pág. 177. Compárese asimismo con Alfonso Rodríguez G. de Ceballos, "Las "Imágenes" de la Historia Evangélica del P. Jerónimo Nadal en el marco del jesuitismo y la contrarreforma». Traza y Baza, 1974, núm. 5, pág. 77-95.

${ }^{6}$ Nació en 1526 en Mula. Véase Jan Navrátil (ed.), Kapitoly z dějin olomoucké univerzity (Capítulos de la historia de la Universidad de Olomouc). Ostrava, 1973, pág. 280. Anna Fechtnerová, Rectores Collegiem. Biblioteca Nacional, Praga, 1993.

7 Trnavský sbornik (Miscelánea de Trnava), Bratislava, 1935, pág. 18. Desde 1596 llegó a ser en Trnava (ciudad en la actual Eslovaquia) rector otro español, Alfonso Carrillo.

8 V. Nešpor, op. cit., nota 5, pág. 49. Otros profesores eran alemanes y austríacos.
} 
Y aquí llegamos al punto que nos interesa. Las obras de construcción fueron encargadas a un arquitecto o maestro de obras llamado en (el antiguo) checo Jan Spaniel, es decir Juan Español; a juzgar por la costumbre general de la época de llamar a los extranjeros, especialmente a arquitectos, por el país de su procedencia, fue -con la mayor probabilidad- español (cómo ejemplo nos servirá un tal Hans Vlach, o sea Juan Italiano) 9. La personalidad de este arquitecto Spaniel a quién le fue subordinado incluso un arquitecto italiano llamado Jeronym Vlach o sea Jerónimo Italiano, de Venecia (otro caso de la sustitución del apellido por la nacionalidad), igualmente activo a la sazón en Olomouc, queda lamentablemente anónima. Lo encontramos mencionado en dos documentos, en ambos casos en lengua checa, que nada aclaran, sólo testimonian.

Debido a que entre miembros del colegio jesuita en Olomouc había más españoles, puede suponerse que el arquitecto realmente fuera español. Con la mayor probabilidad se trataba del maestro de obras del área del ex convento minorita de San Francisco, que ya el obispo Prusínovský pensó convertir en edificios de la nueva Universidad, en 1570. Los datos dados a conocer por el historiador Maliva son importantes. El primer documento dice: «Tenemos noticias de que el maestro Jerónimo (en el original, en checo, Jeronym), quien está esculpiendo las piedras para el edificio de San Francisco, son demasiado pequeñas, de modo que no convendrá al edificio de San Francisco. Por esta razón se le ordenó rigurosamente que las esculpiese de tal forma que le indicase el maestro Juan Español (en el original checo od Jana Španiele)...». Y luego, aparece mencionado en otro documento lo siguiente: "Cuando el maestro Juan Español (en original checo: Jan Španiel) tasase, junto con otros, aquella obra de piedra que Jerónimo hiciera, deberías tú estar presente vigilando que no se nos engañase.... ${ }^{10}$.

Lo que queda es averiguar en archivos españoles si algún arquitecto o maestro de obras español de la misma época puede coincidir con las fechas indicadas.

Pavel ŠTĚPÁNEK

Universidad Palacky de Olomouc

\section{NOTICIAS DOCUMENTALES SOBRE FRANCISCO MATARANA, VIDRIERO Y PINTOR}

Francisco Matarana llegó a Cuenca en torno a 1577, procedía de Génova donde su hermano, el pintor Bartolomé Matarana 1, había firmado un contrato con don Fernando Carrillo de Mendoza, conde de Priego, para trabajar a su servicio ${ }^{2}$. En esa fecha Francisco debía de ser un

\footnotetext{
9 Josef Maliva, «K otázce autorstvi nejstaršich budov olomoucké univerzity" (En torno al problema del autor de los edificios más antiguos de la Universidad de Olomouc) - I. In: Cesty k výtvarnému uměni, Sborník prací Pedagogické fakulty Univerzity Palackého v Olomouci - 1980, SPN Praha, 1980, págs. 178 a 184, refiriéndose al Archivo Regional de Olomouc, de los días 27 de abril y el 10 de diciembre de 1574 que se refieren a la compra de casas vecinas y otros detalles.

10 J. Maliva, op. cit., nota 9, págs. 181 a 183, nota 16, Státní oblastni archiv v Olomouci (Archivo estatal regional de Olomouc) kop. 10, f. 177V, escrito y fechado en Kroměřŕž (residencia de veraneo del obispo de Olomouc), 15-11-1570 por el obispo Prusinovský a Adam Šlechta), f. 237, Kroměříž 8. XI. 1570.

1 Sobre Bartolomé Matarana véase: M. ${ }^{\mathrm{a}}$ Luz Rokiski Lázaro, "Notas sobre Bartolomé Matarana y Juan Gómez", Archivo Español de Arte, núm. 220, 1982, págs. 391, 392; "Bartolomé Matarana, vidriero», Archivo Español de Arte, núm. 9. 238, 1987, págs. 229, 230; “Noticias sobre el pintor Bartolomé Matarana en Cuenca», Cuenca, núm. 31/32, 1988, págs. 7-29.

2 López Torrijos, R., "Bartolomé Matarana y otros pintores italianos del siglo xviı", Archivo Español de Arte, núm. 202, 1978, págs. 184-186.
} 